\title{
Globalization and Perspective of Economic Relations Between Turkey and Albania
}

\author{
Prof. Alqi Naqellari
}

alqinaqellari@gmail.com

\author{
Phd (Student). Rudina Qurku (Feruni)
}

rudinaqurku@yahoo.com

\author{
Doi:10.5901/jesr.2014.v4n2p422
}

\begin{abstract}
In the context of the globalization process, in this paper, are analyzed the Turkish-Albanian economic relations and their perspective. Since Albania and Turkey are two countries with open economies, with a century old common history, it is interesing to analise the economic relations between them. This becomes even more interesting in terms of the features of their economic development. In the past ten years, Turkey has experienced only high rates of economic growth, achieving seventh place in Europe in GDP indicator and the 15th in the world. Turkey has an economy that was not affected by the financial crisis and global recession. The material analyse two main branches of the Turkish economy: agriculture and industry. Furthermore it is presented the dynamics of some key economic indicators, the dynamics of unemployment, GDP and inflation. Moreover, it is exposed the order of the Turkish economy in relation to the European economy and the world economy, Turkey's relations with the world, etc. Recently, the Albanian economy has marked progress. In the paper are presented some of the main economic indicators of economic areas,focusing on such indicators as: GDP, inflation and unemployment. Also, we have analysed the existing bilateral relations between Turkey and Albania. The analysis is focused mainly on Turkish investments in Albania and export-import relations. Changes in economic structure and ownership, associated with corresponding changes in legislation have created the possibility of a new collaboration. Up to now the relationship between the two countries, despite the historical connection, have been unsatisfactory. This fact is confirmed and emphasized by leaders of the two countries. In the material is also considered the prospect of Turkish-Albanian economic relations. It is presented the vision of Turkish Government in 2013. Albanian economy What offers the Albanian economy to the Turkish economy? Which are the strengths and weekness? What are the problems faced by Turkish businessmen in Albania?
\end{abstract}

Keywords: Inflation, unemployment, Gross Domestic Product, economic relations, open economy.

\section{Introduction}

Turkey and Albania are the two Balkan countries with a common history of many centuries. Connections have their roots in the fifteenth century, and continues nowadays. Their cooperation has been versatile: economic, political and social. Relations in different periods are characterized by a dynamic changing, depending on political relations. So we have some cooperation period, until 1912, after 1912, the relationship at the time of the reign of Ahmet Zogu, the period after 1939 until the liberation of Albania, the period from 1945 to 1990, when the Albanian economy was a centrally planned economy and the period after 1990. The period after 1990 has had its oscillations: the rise and decline of bilateral relations. Only in the last 10 years, from 2002 and the following is noticed an intensification of relations in education, defense and the economy in general. In these years the Turkish policy aimed at western Balkan countries such as Bosnia-Herzegovina, Albania, Kosovo, Macedonia, Montenegro, etc.. But despite the introduction of the Turkish capital in the Balkans, Albania has not known any apparent influx of Turkish investments. In comparison with the countries we mentioned Turkish investments occupy a small part. Turkey circulates in Albania a capital of $\$ 420$ million, while Albania exports to Turkey over $\$ 130$ million value of goods. Between Turkey and Albania have been signed over 160 agreements in various fields. It is for this reason that Davutoglu stressed that: "The Albanian people have many important contributions to administrative life, social and cultural Turkish-Ottoman. In our mutual history have left their mark government, military, men of letters, intellectuals and artists too precious of Albanian origin. In the Ottoman Empire there were 28 prime ministers and 36 viziers (ministers) of Albanian origin. Mehmet Akif, the author of our national anthem, and Sami Frashëri, author of the first Turkish dictionary, which at the same time considered one of the most prominent men of letters in Albania, are both of Albanian origin ". Looking at current developments of the two countries, are created the 
conditions and opportunities to intensify the economic relations between them by regaining the lost time. It is this reason that this paper will give an overview of the two economies and the prospects looked mëtejëshme their cooperation. It is this the reason that this paper will give an overview of the two economies and the further prospects of their cooperation.

The method used in this paper is the description one, comparison, analysis and the synthesis.

\section{Elaboration of the material}

\section{An overview of Turkish and Albanian economy}

\section{a) Turkish economy}

Republic of Turkey in 2013 was the first economic power in the Middle East by passing the states such as Iran and Saudi Arabia. It is the sixth economic power in Europe and the strength of fifteen in the world, a member of the G20 and the Customs Union. Turkey has officially launched its accession negotiations with the EU in October 2005. In 2010, Turkey achieved a GDP growth of $9.1 \%$, a figure higher than that of Brazil by $+7.5 \%$ and Germany with $3.7 \%$. Production facility in Turkey is characterized by an overrepresentation of industry and agriculture and an underrepresentation of services. Turkey is an industrial country although agriculture plays an important role in the production of national wealth. Value added of industry represents $26.6 \%$ of GDP against $63.7 \%$ of services and $9.6 \%$ of agriculture. In 2011 it was increased to $8.5 \%$, in 2012 by $3 \%$ and in the first quarter of 2013 it was increased by $4.4 \%$. The development of the Turkish economy has done to change the structure of its branches to GDP taking obvious priority the industrial sector. Below are some indicators full understanding of the structure of the Turkish economy nowadays.

\section{A) Agriculture}

- Turkey has a higher rural population than European. $30.2 \%$ of the total population lives in the countryside versus $26.5 \%$ in the European Union.

- Agriculture occupies an important place in the economy: Turkish agriculture is responsible for $22.9 \%$ of total employment.

- Value added of agriculture or agricultural GDP presents 9:34\% of total GDP against 1.5\% that it occupies in Europe.

- $\quad$ Agriculture occupies half of the land area: $389,000 \mathrm{~km}^{2}$.

- 21.3 million hectares is arable land.

- Cultivated land represents $27.7 \%$ of the national territory against $26 \%$ in the EU.

- $\quad 11,916,000$ hectares are used for crop production.

- $\quad 3.8 \%$ of the national territory is used continuously, versus $2.9 \%$ in the EU.

- Turkey has a more natural agriculture than the EU average. In Turkey is used $96.5 \mathrm{~kg}$ of fertilizer per hectare of arable land, versus $130.6 \mathrm{~kg}$ used in the European Union.

- There is a two-time agriculture less productive than that of Europe: productivity of wheat in Turkey reached to $2,808 \mathrm{~kg}$ per hectare against $5,047 \mathrm{~kg}$ in the EU.

- Turkish agriculture is the penultimate in Europe in terms of value added.

- $\quad 98 \%$ of the rural population has access to an improved water source by $99.7 \%$ in the EU.

- Turkey is the second largest importer of agricultural products in Europe.

- Turkey is the smaller exporter of agricultural products in Europe.

- Exports of raw agricultural commodities represent $0.4 \%$ of exports of goods.

- In 2000, Turkish agriculture was less mechanized than European agriculture.

- $\quad$ In 2010 Turkey with $113,340 \mathrm{~km}^{2}$ of forest area is the fifth in Europe.

- In 2008, watered land in Turkey represented $13.3 \%$ of total agricultural land.

\section{B) Industry}

Turkey, in 2012 has taken the sixteen place in terms of global industrial production. Turkish industry is developed but has an unequal distribution across the country, $22.8 \%$ of the population that provides income by working in the industry remains concentrated in major Turkish cities. 
- The textile industry is the most active

- Turkey ranked 10th in the list of countries for the production of steel. In 2010, total production of steel was 29 million tons.

- Building and construction industry is one of the largest industries in Turkey. Turkish construction companies have a good presence in foreign markets such as Eastern Europe, Russia, Azerbaijan, Central Asia, Iraq and the Middle East.

- The automobile industry is a pillar of the Turkish economy. Automotive sector is the first activity of the country's exports. This sector employs around 500,000 people and has more than 1,000 companies.

- Energy production in Turkey is 32,225 kt of oil equivalent. Turkey is the 8th manufacturer of energy in Europe.

- Since 2009, Turkey has had 102 airports (90 with paved track and 12 with unpaved track) and 21 helicopters. In 2010, there were 102 million passengers.

- Since 2008 there have been 17,502,000 mobile and fixed operational in this country that ranked Turkey the 18th in the world. There are 65,824,000 registered mobile phones in the country which ranked Turkey the 15th in the world.

- Turkey has welcomed more than 31.5 million foreign tourists in 2011.

\section{C) Overview of some key economic indicators.}

- Gross Domestic Product (nominal parity) GDP - 1046 billion \$ (2012)( OCDE )

- Gross Domestic Product (PPP) - 1142 miliardë \$ (2012)

- Gross National Product (GNP) - $€ 671$ billion or $\$ 794.5$ billion (according to PPP) (2012).

- Ranking worldwide for GDP (PPP) - $\quad$ Ranked the 15th in the world

- Increase in $\%$ of GDP- 2003: + 5.3\%, 2004: + 9.4\%, 2005: + 8.4 \%, 2006: + $6.9 \%, 2007:+4.6 \%, 2008:+3.4$ \%, 2009: - 4.8\%, 2010:+9,2 \%, 2011:+8,5\%, 2012:+2.6\%, Q2 2013:+4.4\% .

○ GDP / capita (PPP) - 15200 \$ (2012), 15000\$ in 2011 and 14000 in 2010.

○ Inflation (CPI) - 6,16\%(2012).

- Unemployment rate - $\quad 8,6 \%$ (April 2013).

- The main industries are; The textile industry, food processing, motor vehicles, electronics, mining (coal, chromite, copper, boron), steel industry, petroleum, construction, wood, paper, shipbuilding, etc.

- Foreign Trade:

Exports: \$151.9 billion (2012), \$124.357 billion (10 months of 2013).

The main exported commodities: chemicals, foodstuffs, textiles, transport equipment, fabricated metal products, electronics, etc.

Major customers; Germany with $7.99 \%$, Iraq with $6.02 \%$, Iran with 5.98\%, USA with $5.29 \%$.

- Public Debt - 34.5\% of GDP (2012)

- External Debt - $\$ 350$ billion (2012)

- Public revenues - $\$ 178$ billion (2012)

- Public spending - $\$ 189$ billion (2012)

- Public deficit - $2.1 \%$ of GDP (2012)

- Major trading partners: the European Union by $46 \%$. Turkey is the seventh trade partner of the EU, Russia $10.9 \%$, U.S. $4.4 \%$, etc.

- Turkey's exports to the EU in 2007: € 44.2 billion

- Imports of Turkey with the EU in 2007: $€ 50.2$ billion

- The trade deficit with the EU in 2007: $€ 6$ billion

- Industrial production occupies $30 \%$ of the GDP, services occupy $60 \%$ and agriculture $10 \%$.

- Industrial products occupy $94.8 \%$ of exports, mainly represented by the apparel, textile, electronic equipment, parts for vehicles, steel, glass, etc.

\section{Turkish Economy in global level}

- Takes the first place in the production of nuts, fruits, and dried cherries (figs, raisins, apricots)

- Takes the 6th place in the production of cement,

- Takes the second place in the production of glass wool, 
- Takes the second place in the export of jewelery

- Takesthe 6th place in the export of clothing, is the richest in biodiversity and the largest developing market,

- For the gross national savings takes the place of 72 nd,

- For the percentage of growth Turkey takes the place of $117^{\text {th }}$

- For the GDP / capita (PPP) takes the place of 90th,

- For the size of GDP (PPP) in the world takes the place of $17^{\text {th }}$

\section{Turkish Economy at the European level}

- Ranked in the first place in the production of television sets,

- Ranked in the 4th place in the production of parts for automobiles,

- Takes the first place in the production of fertilizers,

- takes the third place in the production of steel,

- Ranked in the 3rd place in ceramics products,

- Ranked in the sixth place in the fabrication of refrigerators,

- Occupies 4th place in the telephony market,

- Takes the third place in the production of yachts,

- Occupies the 8th place in ship production.

\section{In Turkey:}

○ Net inflows of foreign capital: $€ 8$ billion in 2005 (+240\%), $16 €$ in 2006 (+87.5\%), $16 €$ in $2007(+9.8 \%$ in \$)

- Operate 18,000 foreign-owned companies, one of third of the banks and a quarter of the 500 largest companies are foreign.

- Turkish direct investments in 50 countries have been on the increase ( 77 billion in 2007).

- Tax rate is $20 \%$ for enterprises (OECD average).

- Turkey is a fast growing information society: Turkey has:

- $\quad 35 \%$ increase per year in sales of computers. Turkish companies are 22 to 500 of NTIC companies, which are more efficient.

- 65 million GSM subscribers.

- 19 million internet users.

- 30 national TV channels.

- 250 TV channels locally, etc.

- Privatization. Privatizations in the past 5 years have captured the value of $€ 17.9$ billion.

- Tourism: There were 26 million tourists in 2008. Istanbul was the European Capital of Culture for 2010.

\section{D) The dynamics of the main macroeconomic indicators}

In this part are analyzed the main macroeconomic indicators such as GDP, inflation rate, unemployment rate, etc. Data are given in absolute and relative figures, which are based with corresponding graphs.

\section{a) Dynamics of GDP.}

Dynamics of GDP in percentage for the years 2005-2013 is as follows:

\begin{tabular}{|l|c|c|c|c|c|c|c|c|c|}
\hline Years & 2005 & 2006 & 2007 & 2008 & 2009 & 2010 & 2011 & 2012 & 2013 \\
\hline GDP & 8.4 & 6.9 & 4.7 & 0.7 & -4.8 & 9.2 & 8.5 & 2.6 & $3.4($ II) \\
\hline
\end{tabular}

The data show clearly that the Turkish economy has a sustainable economic growth. Even during the recession Turkey had positive indicators. 
b) Inflation dynamics in percentage.

\begin{tabular}{|c|c|c|c|c|c|c|c|c|}
\hline Years & 2005 & 2006 & 2007 & 2008 & 2009 & 2010 & 2011 & 2012 \\
\hline Inflation & 10.1 & 10.5 & 8.8 & 10.4 & 6.3 & 8.6 & 6.5 & 8.9 \\
\hline
\end{tabular}

The inflation rate has been unstable, although we can observe backdrop trends. This is related to the degree of economic growth. Turkey is a country that has admitted a higher inflation rate in order to increase the rate of GDP.

\section{c) Unemployment rate}

\begin{tabular}{|c|c|c|c|c|c|c|c|c|c|}
\hline Years & 2005 & 2006 & 2007 & 2008 & 2009 & 2010 & 2011 & 2012 & 2013 \\
\hline $\operatorname{In} \%$ & 10.6 & 10.2 & 10.2 & 10.9 & 14 & 11.9 & 9.8 & 9.2 & 9.4 \\
\hline
\end{tabular}

The unemployment rate is stabilized with a tendency to decrease. These three key indicators show clearly the stability of the Turkish economy and its positive prospects.

\section{Some of the reasons for the growth of the Turkish economy}

- The presence of a large internal market. Turkey has over 75 million customers and the private consumption is based on the growth of purchasing power. Turkey has a GDP growth per capita by $7.8 \%$ to $1.4 \%$ comparing with UK.

- Large investments. They represent a significant portion of GDP. In 2010 occupied $20 \%$ versus $17.3 \%$ in the in Germany.

- The Turkish economy is a relatively open economy. Index of Turkey opening to the world is estimated at $48 \%$ of GDP versus 22\% estimated in Brazil and $88 \%$ in Germany. The European Union is the largest trading partner. During the period 2010 - 2011 and 2012, foreign trade is mainly in the negative levels, and has had trade deficit.

- Turkey has increased its economic opening by signing a series of FTAs. By doing so, it has opened new opportunities for export companies favoring their approach to raw materials.

- The Turkish government has a visa waiver policy with third countries to facilitate the exploration of the heads of Turkish companies. On the occasion of the 100th anniversary of the Republic of Turkey in 2023, Turkish government's target is to reach 500 billion dollars in exports.

\section{E) Turkey's relations with the world}

In this section we give a detailed overview of the overall Balance of Payments. Place and role of Turkey in the balance of some European countries is important. Thus:

- Turkey is the fifth largest export to the EU.

- $\quad$ Turkey is the sixth customer (non-EU) of French exports (after the United States, Switzerland, China, Japan and Russia).

- Turkey is the seventh customer (non EU) French supplier (behind China, the United States, Russia, Japan, Switzerland and Norway). In Turkey, any increase of $\$ 100$ in exports is associated with an increase of \$138 in imports.

- Between 2002 and 2010, Turkey has attracted more than $\$ 75.3$ billion of foreign investment. 75\% of FDI have been from the European continent.

- Between 2002 and 2010, Turkish contractors have realized over \$ 130 billion investment abroad. The European continent is the main destination for Turkish investments by about $62 \%$, Asia caught $27 \%$ the Turkish foreign investments, America 7\%, Africa 3\%. Azerbaijan is the country with the highest concentration of Turkish FDI with 21\%, Netherlands 20\%, Germany $20 \%, 8 \%$ and Malta with the U.S. by $7 \%$.

- Between 2000 and 2010, Turkey's foreign debt has grown three times.

- In 2010, Turkey's foreign debt reached \$ 294 billion. External debt structure has evolved to a large extent. The share of public debt has decreased (73\% in 1994 and 32\% in 2010). Public finances are under control and the debt of central government represents $50.7 \%$ of GDP, one of the best performances in Europe.

- Up to now, Turkey has completed FTAs with 30 countries, 11 of which were abolished due to their accession 
to the EU countries. Currently, Turkey has 17 FTAs applicable.

\section{b) Albanian economy}

Albania's economy has experienced a transformation from its communist past to an open economy and free market in the early 1990s. Even though the country is rich in natural resources, the economy is based mainly on agriculture, food processing, lumber, oil, cement, chemicals, mining, basic metals, hydropower, tourism, textile industry, in remittances and informal economy.

\section{A) Some of the key indicators of the Albanian economy.}

- Increase of GDP \$29.86 billion (PPP, 2012)

- Real GDP growth $1.8 \%$ (real, 2012)

- GDP per capita is $\$ 9.600$ (PPP, 2012)

- GDP by economic sectors: agriculture, $20.4 \%$ - 19.1\% industry, 60.5\%-services (2012)

- Inflation (CPI) 2.0\% (CPI 2012)

- Population below poverty line $13 \%$ (2012)

- $\quad$ Gini coefficient 34.5 (2008)

- Workforce 1.071 million (2011)

- Workforce by branches: Agriculture, 47.6\%, 23.0\%, industry, services, 29.2\% (September 2010).

- The official unemployment rate $13.0 \%$ (2012).

- Average gross salary € 246 / \$332 monthly (2010).

- Main industries: products, perfumes and cosmetics, food, and tobacco products, textile-and apparel, wood-, oil-, cement-,--chemicals, mining, basic metals, etc..

- Exports \$2.121 billion (2012).

Export Goods: - textiles and shoes, asphalt, metals and metallic ores, - crude oil, vegetable-, fruit-,-smoking.

Main export partners:

- Italy 44.2\%, Spain 9.0\%, China 6.8\%, Greece 4.9\%, Turkey 4.7\% (2012) is in 5th place

Imports $\$ 5,219$ billion (2012).

Goods imports: machinery and equipment-, food-, textile-, chemical

The main import partners: - Italy $34.9 \%$, Greece $11.7 \%$, China $7.5 \%$, Turkey $5.6 \%$ is in the forth place.-Germany 4.3\% (2012).

Public debt \$ 5,281 billion (31 December 2012).

Revenue $=\$ 3.262$ billion (2012).

Expenses $=\$ 3,669$ billion (2012).

\section{B) Areas where Albania hasw achievements}

Albania has achievements in the field of legislation, in the field of institution building, in the privatization process, the degree of opening to the outside world, in international relations and in the financial sector. In Albania, after the 90s was created a contemporary new legislation, western, in accordance with the principles of the market economy in all fields, political, social, legal, economic, financial, commercial, etc.. The new legislation is based on the fundamental law of the state, in the Constitution of Republic of Albania, is a contemporary legislation and fully harmonized with the standards of the legislation of European Union countries.

Albanian Parliament, during the perios 1997-2012 have adopted more than 2,242 laws. Among which are: Law on Land, the Law on excise duties, VAT Law, the Law on compensation for farmers, the Law on Income Tax, Internal Audit in the Public Sector, Law on Tax Procedures in the Republic of Albania, etc.

The Government of Albania are receiving hundreds of laws, decisions on service and support the economy. Among them mention DECISION No.4 dated 07.01.2010 FOR APPROVAL OF macroeconomic and fiscal framework, for the period 2011-2013.

The Government of Albania has received hundreds of laws, decisions on service and support the economy. Among them mention DECISION No.4 dated 07.01.2010 FOR APPROVAL OF MACROECONOMIC AND FISCAL FRAMEWORK, for the period 2011-2013.

There have been important reforms in the field preschool education, econdary education and university. 9 year old 
system is inserted by 8 year old who has been, is applied Bologna bachelor-master system (3:2). In Albania there are 62 higher education institutions, of which 53 are universities and 14 of these unaccredited of assessment of 2011.

In the field of health, despite numerous absences and undesirable phenomena like corruption of Albania has made significant progress. Furthermore, it is realized the liberalization of market in the field of medical education.

In the field of transport have been undertaken a series of internal reforms and public transportation is almost completely privatized. What would be intended? What objects would have? What objectives would achieve? By what way would Albania implement and realize its objectives? Should all sectors be privatized? Which would be the legal framework? These were some of the problems that defined the model applied by the Albanian government these 20 years of transition.

Private property has become dominant in our economy where over $90 \%$ of currently property has became private and is providing about $80 \%$ of GDP and $85 \%$ of employees.

Privatization periods were:

$\checkmark$ First Period 1993-1999

$\checkmark$ Second period $2000-2012$

Albania has membership and cooperate with all international economic and financial institutions (WB, WTO, IMF, EBRD, GTZ, UNDP, etc.). It has economic relations with over 100 countries. Free trade agreements applied with Albania are:

- Stabilisation and Association Agreement

- $\quad$ Free Trade Agreement Central Europe (CEFTA)

- Free Trade Agreement with Turkey

- Albania and Programme of Generalized System of Preferences (GSP) of the United States of America

In Albania today operate 16 commercial banks with foreign capital and domestic, wholly private.

\section{C) Key macroeconomic indicators}

Albania has achievements in the improvement of macroeconomic indicators. Although in recent years some of them have worsened, the inflation rate has been steadily on the decline. In short, we are providing the dynamics of these indicators.

\section{Dynamics of GDP}

\begin{tabular}{|c|c|c|c|c|c|c|}
\hline Years & 2008 & 2009 & 2010 & 2011 & 2012 & 2013 \\
\hline GDP growth \% & 7.5 & 3.3 & 3.8 & 3.1 & 1.6 & $0.6(\mathrm{IV})$ \\
\hline
\end{tabular}

Albania, excluding year 1997, during all other years has experienced economic growth. In 2008 it was marked the largest increase in the last 10 years by $7.5 \%$. The global recession affected the economy, consenquently this rate fall consistently. So, 2013 has lower growth after the beginning of the global recession. The services sector is the most developed and captures over 50\% of GDP. The weight of the agricultural sector has fallen by $19 \%$, while has increased weight of the construction sector. Thus in Albania are created investment opportunities in tourism, exploitation and processing of subterranean water, in agriculture, infrastructure, etc.

\section{Inflation}

\begin{tabular}{|l|l|l|l|l|l|l|}
\hline Year & 2008 & 2009 & 210 & 2011 & 2012 & 2013 \\
\hline Rate in \% & 2.2 & 3.7 & 3.4 & 1.7 & 1.6 & $1.6(07)$ \\
\hline
\end{tabular}

The inflation rate is a the main indicator that has been consistently realized by the Central Bank forecasts $3+-1 \%$. The main reason of the performance of this indicator is that it generally depends on imported inflation and not by monetary aspect.

\section{Unemployment}

The umber of employees by the year 2009 didn't change but it was 142 thousand. The unemployment rate has changed due to fluctuations in the voice "within the working age" and because of migration. In general we observe these impacts in 
respective groups:

- Employees in the public sector have not changed in number to affect the rate of unemployment

- In the non-agricultural private sector It can be observed a slight increase in the last year.

- The agricultural sector is an sector of unidentified sector because all those in the countryside are regarded as self employed but in fact none of them shed the social security contributions.

- Actual growth in Albania for my judgment finds its expression in the unemployment rate, if we increase the employees then have economic growth.

The unemployment rate in percentage by year:

\begin{tabular}{|c|c|c|c|c|c|c|}
\hline Years & 2008 & 2009 & 2010 & 2011 & 2012 & 2013 \\
\hline Unemployment rate & 12.7 & 13.6 & 13.5 & 13.2 & 12.8 & $12.8(\mathrm{II})$ \\
\hline
\end{tabular}

\section{Existing relations between Turkey and Albania.}

The recession and financial crisis have affected the list of states that invest in Albania to be reversed and for the first time Canada ranked at the top of the list for foreign investment in Albania. Ranking of countries by volume of investments in the Albanian economy is: Canada with 566 million euros, Greece with 525 million euros, Austria with 472 million euros, Italy with 372 million euros, Turkey with 282 million euros and Germany with 85 million euros.

Over the years, Turkey has remained almost at the same position. Turkish investments occupy 8-9\% of the total investment, it has invested approximately 1.3 billion euros in Albania, which represent about $10 \%$ of the investments that it has conducted in the region.

Regarding to Turkish investments in the Balkans, they have grown visible especially in recent years in Albania, Kosovo, Montenegro, Bosnia and Herzegovina and Serbia.

According to the Turkish Statistical Institute, the total volume of exports of Turkey in 2008 in the Balkan countries, including Greece, Romania, Bulgaria, Albania, Croatia, Bosnia and Herzegovina, Kosovo, Macedonia, Montenegro and Serbia are estimated to amount to 10.8 billion U.S. dollars (approximately 17.8 billion euros).

After the financial crisis and global economic recession, total exports to these countries have declined over 6.9 billion U.S. dollars (2012) (5.22 billion euros). countries.

In the first half of 2010, Turkey exported products worthing 3.4 billion dollars (2.75 billion euros) in the Balkan

\section{Turkish exports to Albania}

Albania ranked 70th in terms of Turkish exports in 2012.

Turkish exports of goods in Albania in 2012 were \$255 million, 5.4\% less than in 2011.

The main export categories in 2012 were: iron and steel, textile yarn, fabrics, items, cereals and cereal preparations, electrical machinery and apparatus; articles of apparel and clothing accessories.

\section{Turkish imports from Albania}

Albania was ranked 88th in terms of Turkish imports in 2012.

Goods imported by Turkey from Albania reached \$ 98 million in 2012, 21.4\% less from 2011.

Turkey, in comparison with other countries, occupies a small part of the quantity of import goods in Albania. Italy occupies about 32 percent of Albanian import market. The main import categories in 2012 were: iron and steel; metals, ore, and scrap metal ferite; raw skins and skins, transport equipment and plastics in primary forms.

The trade balance. Trade surplus goods between Turkey and Albania in 2012 was \$ 156 million. Albania is a promising market for Turkish contractors. Turkish firms have held and are holding 19 projects in Albania till now with a total value of 717 million dollars.

The trade balance. Trade surplus of goods between Turkey and Albania in 2012 was \$ 156 million. Albania is a promising market for Turkish contractors. Turkish firms have held and are holding 19 projects in Albania till now with a total value of 717 million dollars.

Turkey and Albania have signed more than 160 bilateral agreements in all areas of cooperation, including economy, trade, energy, defense, education, the environment, national archives, tourism, agriculture, etc. 
Among the main companies that develop economic activity in Albania we mention Kürüm, Albtelcom, National Commercial Bank, Gulistan Educational Foundation, Turgut Ozal, the Alps, Enka etc.

\section{The perspective of Turkish-Albanian economic relations}

\section{A. What is the vision of the Turkish Government until 2023?}

The Turkish government has prepared a program "Vision 2023", Which represents the path of political and economic orientation of Turkey for the next decade. Which are the objectives to be achieved in this program?

- Implementation of an advanced social democracy and political stability in 2011.

Democracy INDEX of Turkey is 5.7340. Turkey is ranked the 88th after Norway (9.8), France (7.7), Poland (7.12), Mali (6.36), Zambia (19.6), Ghana (6:02) and Malawi (5.82). According to the OSCE, which Turkey is a founding member (1973), Turkey holds the world record in terms of jailed journalists (journalists 95, 2012).

- Population: 82.3 million inhabitants.

- Integration into the European Union. In 2014, only one chapter from 35, it reached 3\% of the goal.

- GDP per capita: $\$ 25,076$. In 2011, 42\% of this target is achieved. Current GDP per capita is $\$ 10,498$ (2012).

- GDP (Nominal): $\$ 2,064$ billion. In 2012, about 40\% of this target is achieved (actual GDP $=\$ 784$ milliards (2012).

- Exports: $\$ 500$ billion. In $2011,37 \%$ of this target is achieved.

- Unemployment rate: $5 \%$

- Number of visitors: 50 million. In 2012, $54 \%$ of this target is achieved (the number of settlers 27 million).

- Tourism revenues $\$ 50$ billion. In 2010, 50\% of this target is achieved (actual receipts $\$ 24.7$ billion).

- Exports of high technology: $20 \%$ of manufactured exports. In 2010, only $10 \%$ of this target is achieved (Hightech exports $1.93 \%$ of manufacturing exports of goods)

- The construction of three nuclear power plants. In 2013, no nuclear plant is in operation.

- Primary education $100 \%$. In $2011,97 \%$ of this target is achieved.

- Secondary education: $100 \%$. In $2011,74 \%$ of this target is achieved.

- $36,500 \mathrm{~km}$ of highways divided.

- 10,000 km TGV network.

- Construction of national aircraft for the hunt servants.

- Autonomous military industry.

\section{B. What does Albania provide to the world and in particular to the Turkish economy?}

- Business Registration: Since 2007, the registration of business is done in one day at the National Registration Centre (NRC) for less than 1 euro and the number of steps for starting a new business is reduced from ten to five days.

- Licensing procedures: Licensing procedures in various sectors of the economy are simplified by creating the Business Licensing Center, in July, 2010.

- Public procurement: Public procurement have improved significantly in recent years aiming the improvement of efficiency and transparency as well as strengthening the domination of law state.

- Taxes: Tax reform has contributed to the modernization and improvement of tax regime, has improved the collection of income and reduced the space for discretion and tax evasion.

Tax policy is based on the philosophy of lower taxes and increasing the range of taxpayers.

- Trade policy: A proper trade policy facilitates the integration of the Albanian economy in Eastern Europe regional markets that can compensate the fact that Albania is a small country, opening perspective for service offer.

- Industrial parks and free zones. Among the instruments used to facilitate investment in the country are industrial parks and free zones, the creation of which is initiated by the Albanian government. Actually, in Albania are designated 7 Parks/ Industrial Zone on concession, which are in the initial stages. These parks I area can be invested, managed from different investors through collaboration agreement or transfer.

- The development of transport infrastructure in the country is another priority objective of the Albanian 
government.

- In 1993, Albania adopted a legal framework for foreign direct investments that later mutated. The main features of the current investment regime are:

- The economy is open. Our economy is open to all investors. No previous authorization is required for investment. As a rule, all sectors are open to foreign investment. The law guarantees equal treatment and fair. Investment by foreign and domestic investors are allowed under the same conditions.

- $\quad$ Non nationalization of foreign investment. Foreign Investment Law specifies that foreign investments can not be nationalized or expropriated, except for special cases determined by law and when it is in the public interest. In these cases, the procedures should be conducted without discrimination and with equal compensation to real market value.

- Law protection of foreign investors. Investors in Albania are entitled to be protected by the court for their rights related to their investments. Parties to a debate may agree to submit disagreements to consideration of an arbitration institution.

- Unrestricted ownership. Foreign investment enterprises registered in Albania as legal entities are allowed to own any land.

- The employment of foreign nationals. Companies that invest in Albania are entitled to employ foreign citizens.

- Free transfer of funds. Funds associated with investment may be transferred abroad, in a freely convertible currency at the exchange rate calculated on actual transactions, on the date of the transfer. However, the transfer of these funds may be limited for non-payment of taxes or failure in obligations payments, as well as by the decisions of the courts.

Albania is one of the most important countries of the region in terms of logistics, potential, etc., including the coast, ports, transportation options and other sectors that require investment. This, adding the developments in legislation presents many investment opportunities for Turkish investors.

\section{Other options offered by Albania}

- $\quad$ European integration.

- Regional Economic Integration (CEFTA).

- $\quad$ Wide diaspora.

- $\quad$ Reform of the Education System.

- $\quad$ Reconstruction of Infrastructure.

Strong points offering by Albanian economy.

- Geographic proximity to most of the regions and markets in Europe.

- Qualified labor force with a relatively low cost.

- Culture of work.

- Mineral resources.

- Natural and tourist attractions.

- $\quad$ An acceptable legal environment for investment.

Friendship to the Turkish government and business. Apart from a few minor problems that are encountered in investments, Turkish investors feel satisfied, what may cause the arrival of new investors. In addition, there is friendship toward business, Turkish state, and firms and without doubt, hospitality and warmth toward Turkish citizens. On this point of view, commercial relations should arrive at a more advanced dimension.

\section{Perspective}

$=$ In the field of minerals has serious companies that have shown interest; Turkey should be present in the field of energy.

= Also, Turkey has experience in the field of infrastructure, in which should be grown the capacity of Albanian economy.

$=$ With regard to the textile and construction materials it is necessary that in Albanian market to enter the brands and Turkish firms.

\section{Disadvantages}

$=$ One of the main problems is that in Albania is not sufficiently recognized the competitive and industrial power of Turkey, including the negative image about Turkish products.

= Lack of information of Albanian firms about the power of manufacturing industries of Turkey. Now in Turkey can be produced in high-quality any product that fits the global standards. Turkey has become one of the most industrialized 
countries in the world and as such, increasing the cooperation with Albania would bring in a point even better competition in the country.

=Mutual information. In the future, we believe that firms which will be located in Albania, will give their contribution in terms of development of both countries.

Problems faced by Turkish businessmen in Albania:

According Attaché of Turkish Embassy in Tirana Muharram Gian problems that faced the Turkish business to invest in Albania or after having invested are:

1. Legislation should become stimulant of investment.

2. Problems with land tapis.

3. Malfunction of industrial areas.

4. Appearance of bureaucracy in the system of penalties and taxes.

5. The reference prices are not sufficiently transparent. Some companies pay $100 \%$ of reference price. This poses an obstacle to the Albanian consumers to consume cheaply.

6. Along the way encountered problems that are not resolved with necessary speed.

7. Problems that arise in the judicial system.

\section{Conclusions and Recommendations}

\section{Conclusions}

Republic of Turkey in 2013 is the first economic power in the Middle East by passing the states such as Iran and Saudi Arabia. It is the sixth economic power in Europe and the fifteenth in the world, a member of the G20 and the Customs Union. Turkey has officially launched its accession negotiations with the EU in October 2005.

The performance of the Turkish economy is explained by the presence of a large internal market. There are over 75 million customers and private consumption is based on the growth of purchasing power. Turkey shows an increase of GDP per capita by $7.8 \%$ to $1.4 \%$ which has UK. There are huge investments that represent a significant portion of GDP. In 2010 accounted for $20 \%$ versus $17.3 \%$ in the in Germany.

The Turkish economy is relatively an open economy. Turkey has one of the biggest agricultural economies of the Middle East and Oriental. Since 1950, agricultural production has increased significantly thanks to the introduction of mechanization, better diversity of plants and fertilizer use.

Turkey ranks 10th in the list of largest counties for the production of steel.

Building and construction industry is one of the largest industries in Turkey. Turkish construction companies have a good presence in foreign markets such as Eastern Europe, Russia, Azerbaijan, Central Asia, Iraq and the Middle East.

The automobile industry is a pillar of the Turkish economy. Automotive sector is the first activity of the country's exports. This sector employs around 500,000 people and has more than 1,000 companies.

Energy production in Turkey is $32,225 \mathrm{kt}$ of oil equivalent. Turkey is the 8th largest manufacturer power in Europe after Britain with 148,765 kt of oil equivalent, France with 135569 kt of oil equivalent and Germany with 131,349 kt of oil equivalent.

Turkey has welcomed more than 31.5 million foreign tourists in 2011. Tourism has brought to the country more than $\$ 23$ billion in 2011. billion.

In 2010, Turkey exported more than U.S. \$ 113 billion good. In 2010, Turkish imports totaled over U.S. \$ 185

Turkish direct investments in Albania from 100 million dollars in 2004, have gone over 1.5 billion dollars, employing over three thousand Albanian citizens. In Albania operate 92 (2011) Turkish company (in 2012 over 100), most of them are small and medium enterprises, in areas such as construction, iron-steel, mining, telecommunications, education, healthcare, energy, banking, manufacturing, etc. Common ambition between the two countries is overcoming this value of trade exchanges.

Albania is ranked the 70th in terms of Turkish exports in 2012. Albania ranked the 88th in terms of imports Turkish imports in 2012.

Turkey and Albania have signed more than 160 bilateral agreements in all areas of cooperation, including: economy, trade, energy, defense, education, the environment, national archives, tourism, agriculture etc.

Despite the advantages Albania and Turkey do not have good levels of economic cooperation. This has been confirmed by Sefik Kantar, vice president of the Association for Economic Development and Cooperation in Economic 
Symposium "To improve economic relations between Turkey and Albania". According to Kantar, trade exchanges between the two countries are not at good levels, "Our two countries are brother countries, the Turks and Albanians are brothers because we have a number of traditions and common culture. But it is not the same from the economic viewpoint. Levels of economic cooperation between our two countries are not very good and we wish that this symposium have effects, as the level of economic cooperation is not dignified in comparison with political relations ".

In Albania, operate over 100 Turkish companies. Turkey ranks fourth in terms of strategic trade partners of Albania, remaining behind Italy, Greece and Germany.

\section{Recommendations}

It is necessary to work towards the elimination of barriers for the absorption of Turkish and foreign investment.

- The problem of image is one way to ensure a rapid change for Albania's image abroad.

- Problems and conflicts related to land ownership, bureaucratic procedures for registration of property rights, for approval and issuance of construction permits have always created a barrier to foreign investment.

- The informality level of the economy is also a direction that should be aimed to improve in the future, to ensure fair competition in the market.

- The perception of a possible political and economical risk by the country's potential foreign investors.

- Poor functioning of public institutions, corruption, trafficking and weak enforcement of the law.

- Inefficiency and high cost of infrastructure (transport, energy, water) and the lack of industrial parks for FDI oriented by export and tourism.

- Unavailability of financial services, banking and non-banking.

- Gaps in the legal framework and its implementation.

- Weak financial infrastructure.

In the field of Turkish business perspective should be taken into consideration:

- Turkey should be present in the field of energy, because in the field of minerals has serious companies that have shown interest.

- Turkey's experience in infrastructure should be utilized because it will impact on the capacity of the country.

- With regarde to textile and construction materials, in the Albanian market should penetrate wellknown brands Turkish firm.

- To be known that Turkey is already one of the most industrialized countries in the world as such, increasing the cooperation with Albania would bring in a point even better competition in the country.

- Legislation should be stimulant of investment.

- Should be resolved the problems with land tapis

- Improvement of efficiency of industrial areas.

- Fighting bureaucracy in the system of penalties and taxes.

- Reference prices are not transparent enough, so they should be transparent.

- The elimination of any problems which arise in the judicial system.

- Must be worked in order to be known in Albania the competitive and industrial power of Turkey. Therefore it should be worked toward advertising the power of the Turkish business opportunities it has to invest in Albania.

- Should be removed the negative image about Turkish products

\section{References}

Hajro Limaj, "Midis Ankarasë dhe Tiranës",Tiranë 2012

Në Turqi, një e treat me gjak shqiptar. 28.10.2013. Leonard Veizi, Abe Hitaj. G.Ballkan

Turkish Statistikal Institute, ŵŵw.hazine.org.tr

Kacaroglu: Investimet Turke në Shqipëri në Nivele të Kënaqshme. Intervistë

Banka e Shqipërisë. Open Data Albania. Investimet e Huaja Direkte në Shqipëri Sipas Shtetit të Origjinës 2005-2010.

FORUMI I BIZNESIT TURQI - SHQIPERI" 06 Prill 2012 ne Anbientet e TOBB .Materiale.

Bilateral Investment Promotion and Protection Agreement(1996) and Double Taxation Prevention Treatment(1996).

Economic, Trade, Industry and Technical Cooperation Agreementbetween Turkey and Albania,2 August 1988.

RAPORT MBI INVESTIMET E HUAJA DIREKTE NË SHQIPËRI, 2011.Maj 2012.UNCTAD 
Erdogani nxit për të ardhme të përbashkët të vendeve të Ballkanit, 28/09/2011. Artikull

Ekspertët sugjerojnë një linjë ajrore të përbashkët për Ballkanin Perëndimor, 12/04/2012. Artikull

Indeksi Global i Paqes vë në dukje shqetësimet në vendet e Ballkanit, 26/06/2013. Artikull

Drazhen Remikoviç për Southeast European Times në Sarajevë -- 08/05/12. Ndikimi i Turqisë në BiH dhe Ballkan është në rritje

Bledar Komini. Inputet turke në Ballkan.

Davutoglu: Mburremi me marrëdhëniet Turqi-Shqipëri . Wednesday, 05 September 2012.

Lorenc Vangjeli. Shqipëri - Turqi: Dritëhijet e një Memorandumi. 24 Shkurt 2010 - 15:37 . Revista MAPO.

Ahmet Davutoglu, "Thellësia strategjike", Monografi e botuar në vitin 2001.

AMBASADA TURKE NE TIRANE. PERFAQESIA E TREGETISE SE JASHTME. Nr Dosjes : B.02.1.DTM.TR.01.01/539. Tema : Informacion. Tirane,17.07.2007. Serpil KAÇAROĞLU. Keshilltarja Tregtare.

RAPORT MBI INVESTIMET E HUAJA DIREKTE NË SHQIPËRI, 2011.Maj 2012.UNCTAD

Raport Statistikor, 2008, 2009, 2010, 2011, 2012, maj 2013. Banka e Shqipërisë.

Central Bank of the Republic of Turkey.

Producer Price Index 2004-2013. (2003=100) (TURKSTAT).

Consumer Price Index (2003=100) (TURKSTAT).

Analytical Balance Sheet.,

Financial Stability Report.

GDP-By Kind of Economic Activity in Basic Prices (At Current and Fixed (1998) Prices) (TURKSTAT)(Neŵ Series) .

GDP-Expenditure based (At Current and Fixed (1998) Prices)(TURKSTAT)(Neŵ Series).

Exchange Rates, etc.

LISTA E FIRMAVE TURKE NE SHQIPERI - Müşavirlik Ŵeb ...

Banka Kombëtare Tregtare/BKT 